\title{
MUC5AC wt Allele
}

National Cancer Institute

\section{Source}

National Cancer Institute. MUC5AC wt Allele. NCI Thesaurus. Code C90333.

Human MUC5AC wild-type allele is located in the vicinity of $11 \mathrm{p} 15.5$ and is approximately $146 \mathrm{~kb}$ in length. This allele, which encodes mucin-5AC protein, is involved in the formation of the mucosa of the respiratory and gastrointestinal tracts. This gene is aberrantly expressed in many carcinomas and in Barrett esophagus. 